\title{
SYNECTICS-SIMULATION GLOBALE MODEL IN FRANÇAIS DU TOURISME THROUGH MULTIMEDIA BASED ON LOCAL WISDOM
}

\author{
${ }^{1}$ Iim Siti KARIMAH, ${ }^{2}$ Tri Indri HARDINI, ${ }^{3}$ Farida AMALIA \\ 1,2,3 Universitas Pendidikan Indonesia, Indonesia \\ ${ }^{1}$ iimsitikarimah@gmail.com; ${ }^{2}$ tihardini@upi.edu; ${ }^{3}$ faridamalia@gmail.com \\ Received April 8, 2016 | revised from April 16, 2016 I accepted June 25, 2016
}

\begin{abstract}
RÉSUMÉ. Cette recherche vise à concevoir du modèle d'apprentissage SynecticsSimulation Globale en se basant sur la sagesse locale dans l' apprentissage du Français du Tourisme pour améliorer la créativité des élèves à faire des scénarios d'un film dont le thème est la vie du tourisme. Afin d'effectuer cette recherche, nous adaptons l'approche Research and Developpement (R\&D). Les résultats qui ont été obtenus sont les suivants: 1) La conception de modèles Synectics-Simulation Globale sur l'apprentissage du Français du tourisme;2) les matières d'enseignement du Français du tourisme; 3) les Scénarios des films relative au tourisme. Ces résultats pourraient améliorer la créativité des apprenants en faisant la simulation de la vie réelle du monde touristique en se basant sur la sagesse locale.
\end{abstract}

Mots-clés: créativité, français du tourisme, modèle d'apprentissage, synectics-simulation globale.

\begin{abstract}
This study aims to design a learning model of Synectics-Simulation Globale in Français du Tourisme courses to improve students' creativity in making scenarios of a film of the life of local-wisdom tourism. The research employed Research and Development (R \& D) approach. The participants of the study were 40 students of Français $d u$ Tourisme course. The results showed that the design of Synectics-Simulation Globale learning model in Français du Tourisme course encouraged students' creativity. Besides, the designed teaching materials for Français $d u$ Tourisme courses and the screenplay about tourism created by learners improved students' creativity by simulating real life world of tourism based on local wisdom.
\end{abstract}

Keywords: creativity, français du tourisme, learning models, synectics-simulation globale.

\section{INTRODUCTION}

Universitas Pendidikan Indonesia (UPI) has a strong commitment to reach its vision and missions, which are (1) to provide quality education to develop prospective educators that can compete globally, (2) to develop theories of education and other disciplines to become a cornerstone in the establishment of national education policy (Universitas Pendidikan Indonesia, 2014, p.4). As a teacher education institution (LPTK), UPI has also a responsibility to fulfill the needs of communities for professional, creative, and proactive educators in any fields. In line with these vision and missions, the French language department of FPBS UPI strives to produce quality graduates who can compete both academically and professionally and also to contribute to the enhancement of human resources. In this 
term, human resources are the students and graduates who have creativity to make innovative works.

Français $d u$ Tourisme as one of the subjects FOS (Français sur Objectifs spécifiques) is packaged to equip the students with required knowledge and skills that are necessary for students not only to take part in education but also to contribute to meet the needs of the wider community in the field of tourism. This is consistent with the development of tourism in Indonesia which has shown a rapid growth in recent years. According to statistics of the Ministry of Tourism, the number of foreign tourists coming to Indonesia continues to grow, reaching up 785, 523 tourists in 2015 (Kementerian Pariwisata, 2012), and more than ten thousand of them were tourists from France. For that reason, FOS is present in order to answer the needs of human resources in the field of tourism.

The process of teaching-learning in the Français $d u$ Tourisme courses is directed to prepare human resources who have an active and creative role in the world of tourism. As to this, making a film as teaching-learning product using models of Synectics-Simulation Globale with the tourism theme based on local wisdom in the Français du Tourisme courses is an option to develop the ideas and creativity of students. This is in line with the results of research conducted by Liliasari (2003) which concluded that "prospective teachers need to be equipped with a highlevel of thinking skills that needed to improve the quality of Indonesian human resources of the future". The achievement of the quality of graduates pursued through the development of models of SynecticsSimulation Globale. Based on those various phenomena, the models can be applied.

This study was conducted to investigate the teaching-learning process of Français du Tourisme course, to find out appropriate the materials learning using Synectics-Simulation Globale model, and to examine the creativity of students in making learning screenplay with the tourism theme based on local wisdom. This study highlighted learning process and provided modeling and material development through the creation of film scenario base on the themes in the Français du tourisme courses in the French language department of FPBS UPI Similar study has been conducted by Hardini, Karimah, and Jubaedah (2013) entitled Français des Medias courses to improve student creativity in making media campaign. The results show that Synectics model is found to be motivating and improving the creativity of the students in creating promotion media in French. In contrast to the previous study, the current study combines synectics models that focus on individual psychology and the development of creativity with globale simulation models that emphasize on a collective learners activity based on the technique of role playing and the creation of an imaginary world.

Synectics model is a teaching model oriented to individual self-development which focuses heavily on individual psychology and creativity development (Hardini, 2014). This model was first designed in the industrial sector by Gordon for the purposes of meeting the demands of individual activities in their groups to solve problems and to improve products (Joyce \& Weil, 1992, p.236). After the success in the industrial sector, the model is implemented in the school sector with similar objectives: to increase the student's creativity to the expected level where it can help them to solve problems creatively.

According to Gordon, Synectics model views creativity in four principles. First, creativity is daily activity. Creativity is a part of life for every individual that occurs daily and continually happens until the timeworn. With the help of Synectics model, it is expected to improve the problem-solving through creativity expression, empathy and realization of how important of social relationship in problem-solving. Secondly, creativity is not mysterious, hence it can be learned. According to Gordon (Joyce and Weil, 1992), once individuals learn the basic of creative process, they can study and improve their sense of creativity independently, or as a member of group or society. This can be boosted by analyzing and picturing the training procedure that can 
be implemented in school or others situation. Thirdly, creativity is created in every field. Creativity is everywhere. Even though it is against with a common belief that creativity is only related to art, it is found that creativity can be found in art, language, science and even technology. Lastly, the discovery process of individual creativity is supported by the discovery of group creativity. Individuals and groups have an ability to discover and develop creativity with the same result on certain range of skills. This can be improved by the experience of the individuals that is supported by the group's finding.

The Synectics model can be implemented by conducting six steps. The first step is describing the current situations. In this step, teachers ask the learners to describe their current situations that can be a problem during that time. The second step is Direct Analogy Process. Learners are asked to create the direct analogy to solve as many problems as possible, in which later the ideas will be selected and developed. The third step is Personal Analogy in which learners are asked to build the selected analogy from the second step. The fourth step is Conflict Stability where learners are trying to understand the problems from step one to three, and several conflicts that have been stabilized and selecting one of the conflict. The fifth step is Direct Analogy in in which learners state and choose the direct analogy based on the conflict from step 4 . The sixth step is testing the efficiency rate in completing a task. Teachers ask the learners to start from the beginning and re-do the whole process by using synectics process.

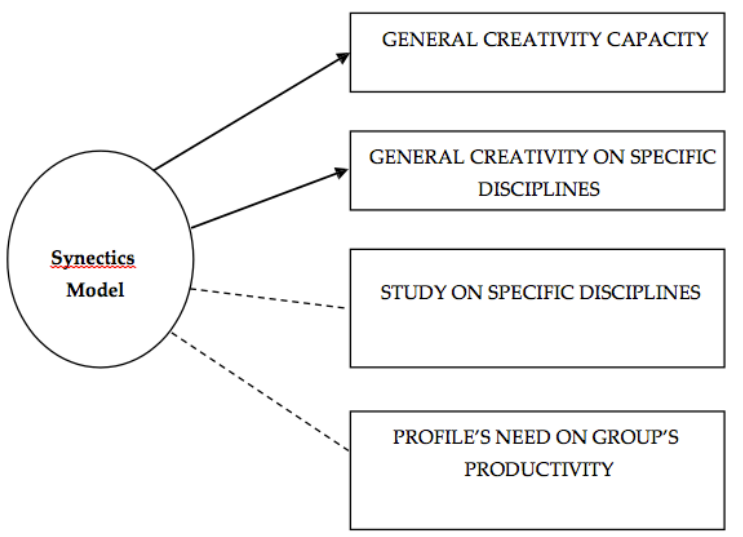

Instructional effect

Following effect

Figure 1. Diagram Synectics Model (Joyce \& Weil, in Hardini, 2014)

Simulation Globale is a technique of foreign language learning that centralizes on collective activities such as role-playing. When a teacher encourages his students for role-playing, he actually creates a simulation. In this technique, learners create a world that is close to their reality which enables learners to interact and simulate their language functions. According to Capriles (2004), this technique encourages the establishment of imaginative pedagogic environment into a class where learners play their roles as the explorers with false identities in a game.
The purpose of this technique is to improve learners' language production in written or in spoken or both in a project. A variety of language production will help the learners in the process of language acquisition.

According to Yaiche in Apollon (n.d.), it required to have at least 40 hours to apply this technique. However, this requirement takes much time and becomes inappropriate to some learning programs. Thus, the duration can be decreased accordingly to the needs and the learning program as long as the learning program follows the steps in the 
model. Below are the steps to be followed when applying the simulation globale technique:

1. Establishing the fictional place and environment that will be simulated

2. Identifying the fiction roles for learners

3. Developing and creating the interacting

4. Adding the elements of event and conflict

\section{METHOD}

This study used the Research and Development approach (Moleong, 2010) aiming to answer the research questions that have been formulated. This approach includes three stages consisting of preliminary study, model development, and model validation. This current study was a preliminary study of a three-year research scheme.

There were several activities conducted in this preliminary study. The first, literature related to learning model of SynecticsSimulation Globale and students'creativity in making scenario of film on the tourism theme based on local wisdom were studied and analyzed. The second, the learning in Français du tourisme courses in the Department of French Language Education in FPBS UPI was designed. The third, a model of Synectics-Simulation Globale on learning to enhance student creativity in making the scenario of the film was designed. The last, instructional materials Français du tourisme to enhance student creativity were developed.

The study was conducted in the Department of French Language Education FPBS Universitas Pendidikan Indonesia. The participants were 40 students in six-month Français $d u$ Tourisme courses. Some documents such as the lessons plans and several related books were analyzed to support the study..

\section{RESULTS AND DISCUSSION}

The results showed that learning model of tourism in French language by applying the Synectic-Simulation Globale encourages learners' creativity.

\section{The learning implementation of} Français $d u$ Tourisme courses

The implementation of learning in Français $d u$ Tourisme courses was based on the concept of learning adapted from Synectics Model and the concept of adapted Competency-based Assessment. It was based on current situation and condition that occur in learning process. The results of this preliminary study showed that the model and assessment require students' high creativity to produce a high quality scenario both in tourism content and language skills.

In the step of model implementation, the learning process were divided into two steps:

1. Establishing the fictional place and environment that was simulated. In this step, learners decided a "theme-place" from the simulation project to be played. The fictional place was the theme related to learning process, such as a village or an island. This step encouraged learners to decide the theme-place and to describe the place with their respective elements. The places on the model included: (1) Travel Agent (l'agence de voyage) Célibatour, (2) France University Garden (le Jardin de l'université), (3) Airport (l'aéroport), (4) Hotel (l'hôtel), (5) Art Centre (le théâtre), (6) Tanah Lot, (7) Souvenir Shop (le magasin de souvenir) (8) Airplane (l'avion), (9) Money changer , and (10) Police Station (commissariat de police).

2. Identifying the fictional character that is going to be played. At this stage, learners did a simulation of the selected characters. They were required to elaborate a story and expand their characters, such as physical appearances and traits, in the simulation process. The lecturer gave some linguistics materials that were relevant to the theme, and learners imagined a scenario that suited to their characters. The example was shown below:

"Quelques clients francophones se présentent au restaurant. Le serveur/la serveuse prend leurs commandes. Ils se renseignent auprès $d u$ serveur/de la serveuses s'il s'agit des repas typiques balinais ou indonésien". (Some guests from France came to a restaurant. 
The waiter served them. The guests asked the waiter if the food served is a typical Balinese or Indonesian food).

\section{The Building of Synetic-Simulation Globale model in Français $d u$ Tourisme course.}

In designing the learning model of Français $d u$ Tourisme courses, ten steps according to the theory of Kemp in Hardini (2009, p.5) were adapted. The steps were as follows:

1. Needs assessment of the course material was obtained from syllabus review. From this review, general learning objectives were formulated, where the students were expected to communicate in French language professionally whether it is spoken or written in terms of tourism, especially in the hospitality and restoration by using the local wisdom. Local wisdom is a local culture that is practiced in certain communities, such as local values, procedures, customs, and practices. To achieve this purpose, some materials were established in accordance to the subject, and the focus was heavily on speaking skill.

2. The subject matter and type of tasks were selected and assigned by researchers to be further formulated into indicators of achievement in learning objectives.

3. The subject matter in the study included (1) premiers contacts; (2) acceuil; (3) animation; (4) promotion d'une destination; (5) vente d'un produit touristique; (6) guide.

4. The target population were the students who took Français de Tourisme course, batch 2015/2016. The course was offered in the 5 th semester. Thus, the population was expected to have adequate French skill.

5. After the subject matter had been decided, some materials were determined with reference to various sources. The material references included: (1) se présenter et parler de son métiers; (2) engager une conversation téléphonique; (3) renseigner à l'aéroport; (4) accueillir les passagers; (5) Informer les voyageurs; (6) Animer un village de vacances; (7) Savoir modifier une réservation; (8) Savoir accueillir un client à l'hôtel; (9) Savoir accueillir un client au restaurant; (10) Savoir accueillir un client au standard; (11) Savoir décrire un repas; (12) Savoir prendre une commande au restaurant; (13) S'informer pour bien guider; (14) Savoir présenter un monument; (15) Gérer un groupe; (16) savoir présenter la note.

6. Specific objectives were developed based on those materials.

7. From the treatment process, the learning design was formulated into learning scenario that described the whole of learning process.

8. A number of tools were used to support the learning process, including cameras, video projectors, laptops, and others.

9. Process evaluation and the results of the learning were obtained from the recording and simulation processes.

10. To measure the mastery of the material, a test instrument was developed. The test focused on speaking skill similar to DELF A2 level, such as students were asked to present one tourism object in Bali.

\section{The Development of Teaching Materials of Français du Tourisme}

The teaching materials of this course were arranged and adapted from the designed model. Some scenarios were set accordingly to the selected themes and resources. Below were the produced canevas for the entire learning process: (1) se présenter et parler de son métiers ; (2) engager une conversation téléphonique;(3) renseigner à l'aéroport; (4) accueillir les passagers; (5) Informer les voyageurs;(6) animer un village de vacances; (7) Savoir modifier une réservation; (8) savoir accueillir un client à l'hôtel; (9) Savoir accueillir un client au restaurant; (10) Savoir accueillir un client au standard; (11) Savoir décrire un repas; (12) Savoir prendre une commande au restaurant; (13) S'informer pour bien guider; (14) savoir présenter un monument; (15) Gérer un groupe ; (16) savoir présenter la note.

Students were expected to develop the idea from the above scenarios. The results of idea development, a story of tourism with 22 scenarios were successfully created as an 
educational film. Here are some examples of these scenarios:

\author{
Scène 3 \\ Agence de voyage(En reunion) \\ Rizky N.M : Ketut Barbara (Directeur) \\ Clara C : Kadek (Employé 1) \\ Dheny $M:$ Putu (Employé 2) \\ Rifat T : I Nyoman (Employé 3)
}

Le Directeur fait la réunion avec ses employés. Ils parlent de revenu et le programme de voyage

Directeur : Bonjour...! Comment allez-vous. Dans cette réunion, on va parler de notre revenu de la semaine précédente.

Kadek : On a reçu beaucoup de revenus. Par exemple, Beaucoup de touristes ont acheté des billets. Comme les billets d'avion, les billets de train, etc. Parce que c'était la saison de vacances. Et il y a beaucoup de touristes qui ont acheté notre programme de voyage

Directeur : : Oui, j'espère qu'on peut avoir beaucoup de réservations cette semaine.

Putu : J'oublie, hier il y a un email de Monsieur Dubois. Il a acheté un programme. Ils vont passer leurs vacances pendant trois jours. Pour le billet, j'ai déjà vérifié et il n'y a que Garuda Indonesia qui fournit pour cette date. Alors, ils vont arriver le 10 octobre à Jakarta.

Directeur $\quad:$ Vous avez déjà réservé le billet ? Et quand-t-ils vont à Bali ?

Putu : Ils y vont dans le même jour. Mais s'il y a un petit problème. Comme, il fait mauvais, ils vont partir au jour suivant.

Directeur : : ok, pour le billet, c'est déjà claire. Ensuite, le programme des activités pendant le voyage? Monsieur I Nyoman, s'il vous plaît!

I Nyoman : Au premier jour, je pense qu'ils vont reposer pendant quelques heures à l'hôtel. Après ça, ils prennent le déjeuner au restaurant.

Directeur : : D'accord. Alors, l'hôtel et restaurant ont été réservés?

Kadek : : Pour l'hôtel et restaurant, j'ai déjà réservé de l'hôtel et le restaurant.

Directeur : : Ok, on s'arrête. Je vous remercie de votre travail. Merci beaucoup et bonne journée!

Scène 5

Dans la portée d'avion

L'hôttese de l'air: Sabrina

Le pilot : Fery

Le passager : Dei

Dans la porte d'avion, Les hôtesses de l'air accueillent les passagers.

L'hôtesse de l'air : Bonjour, la cabine 8D est dans votre gauche, s'il vous plait

Le passager : Merci.

Après que tous les passagers soient dans leurs sièges et avant l'atterrissage, il y a quelques annonces.

Le pilot : mesdames et messieurs, je suis Charles Duques et je suis votre chef de cabine. Bienvenue à bord Air Fery AF-737 à la destination Jakarta, Indonésie. Notre temps de vol devra 16 heures et 35 minutes. Nous volerons à une altitude de 30.000 pieds à une vitesse de 900 miles par heure.

L'hôtesse de l'air : Vérifiez autour de votre siège pour tous les effets personnels que vous avez amenés à bord. Puis, assurez-vous que vos dossiers de sièges et votre tablette sont dans leur position verticale. Assurez-vous également que votre ceinture est correctement fixé. Aussi, nous vous conseillons à partir de ce moment que toutes équipements électroniques doit être désactivé pendant l'atterrissage. Pour votre préparation s'il y a un accident, au-dessous de votre siège, nous vous préparons le gilet de sécurité, vous tirez le sifflet pour se déployer. Les portes de secours sont à gauche et à droit la cabine. Si vous avez besoin d'aider, vous pouvez nous appeler. Nos hôtesses de l'air sont toujours prêtes à vous aider. Merci de votre attention

L'hôtesse de l'air : pardon, vous devez serrer votre ceinture de sécurité, monsieur

Le passager : :ah, pardonnez-moi.

L'hôtesse de l'air : pardon, vous ne pouvez pas téléphoner pendant l'atterrissage vous devez désactiver votre téléphone,

s'il vous plait

L'hôtesse de l'air : bonjour madamel monsieur/ mademoiselle, voulez-vous prendre le bonbon?

Les passagers : ah, bien sûr. Merci 


\title{
Scène16 \\ Presentateur: Azmi \\ "Tari Kecak" à Bali
}

\begin{abstract}
Présentateur : Bonjour les spectateurs, Bienvenue à Bali. Avant de commencer le spectacle permettez-moi de me présenter je m'appelle Azmi. Je suis présentateur ici.

La Danse Kecak est un chour de percussions vocales balinais accompagnant originellement des transes lors de rituels. Le Kecak n'est accompagné d'aucune musique. C'est un chant polyphonique sur 2 syllabes (chak-a-chak-a-chak) produit par un choeur d'hommes qui a donné le nom à cette danse. Jouée par un groupe d'au moins de 50 hommes qui dansent en cercle autour de flammes des torches en bambou. De toutes les danses de Bali vu aujourd'hui, la danse Kecak est peut-être la plus dramatique. Tiré de l'épopée hindoue Ramayana, la danse raconte l'histoire du prince Rama et son sauvetage de la princesse Sita, qui a été kidnappée par le roi méchant de Lanka. Au lieu de cela, une troupe de plus de 150 hommes torse nu servir le chœur, faire une cacophonie merveilleuse de synchronisation.
\end{abstract}

Voilà, vous voulez jouir ce spectacle?

Amusez-vous bien!

\section{CONCLUSION}

In conclusion, the study of The Synectics-Simulation Globale model in Français $d u$ Tourisme courses had fulfilled the characteristics and stages accordingly. The design was the combination of Synectics model focusing on motivating individuals to increase their creativity in developing local wisdom tourism and Simulation Global model which demanded students to develop their imagination in deciding simulated fictional place, determining fictional identities, developing interactions, and adding conflict elements. In addition to this, the Synectics-Simulation Globale model on Français du Tourisme courses was conducted in accordance with the theories used. The results were the lesson plans of Français $d u$ Tourisme for one semester. Lastly, the developed teaching materials in Français $d u$ Tourisme courses was adapted to the demands of the depth of material that enhance the creativity of the students in making the scenario that matches the theme of tourism world. The development of the teaching materials produced 16 speeches, including (1) Se présenter et parler de son métiers ; (2) Engager une conversation téléphonique; (3) renseinger à l'aéroport; (4)acceuillir les passagers; (5) Informer les voyageurs; (6) Animer un village de vacances; (7) Savoir modifier une réservation; (8) Savoir accueillir un client à l'hôtel; (9) Savoir accueillir un client au restaurant; (10) Savoir accueillir un client au standard; (11) Savoir décrire un repas; (12) Savoir prendre une commande au restaurant; (13) S'informer pour bien guider; (14) Savoir presenter un monument; (15) Gérer un groupe ; (16) Savoir presenter la note

\section{ACKNOWLEDGMENTS}

On this occasion the researchers had like to express our acknowledgments to all those who have helped the realization of this article. Our gratitude also goes to especially DIKTI through UPI who has funded our research.

\section{REFERENCES}

Apollon, O. (n.d.). La simulation globale au service de la vie de classe. Retrieved from http://www.acrennes.fr/pedagogie/lettres/lp/simgl ob.htm

Capriles, A. (2004). La simulation globale. Retrieved from http://www.edufle.net/Lasimulation-globale

Hardini, T.I. (2009). Model Pembelajaran Jarak Jauh Bahasa Indonesia Bagi Penutur Frankofon Melalui Teknologi Multimedia. SPs UPI : Disertasi Tidak Diterbitkan.

Hardini, T.I., Karimah, I.S, and Jubaedah, Y. (2013). Rancang Bangun Model Synectics Pada Pembelajaran Français des Médias untuk Meningkatkan Kreativitas Mahasiswa dalam pembuatan Media Promosi. (Research Report). Bandung : Lembaga Penelitian dan Pengabdian Kepada Masyarkat, Universitas Pendidikan Indonesia.

Hardini, T.I. (2014). Rancang Bangun Model Synectics Pada Pembelajaran Français 
des Médias untuk Meningkatkan Kreativitas Mahasiswa dalam pembuatan Media Promosi. Cadence, 18(1), 1-9.

Kementerian Pariwisata. (2012). Statistik Wisatawan Perancis. Retrieved from www.kemenpar.go.id/asp/ringkasa $\underline{\text { n.asp?c }=110}$
Liliasari. (2003). Pengembangan Keterampilan Berpikir Tingkat Tinggi Mahasiswa Caon Guru melalui Model Pembelajaran Kimia. Mimbar Pendidikan, 22(2).

Moleong, L.J. (2010). Metodologi Penelitian Kualitatif. Bandung: Remaja Rosdakarya

Universitas Pendidikan Indonesia. (2014). Informasi UPI. Bandung: UPI Press. 